\title{
LEARNING STYLES OF SECONDARY SCHOOL STUDENTS IN ANAMBRA STATE, NIGERIA: IMPLICATIONS FOR GUIDANCE AND COUNSELLING
}

\author{
Ada Anyamene ${ }^{1}$, Princewill Ikechukwu Odalonu² \\ ${ }^{1}$ Professor, Department of Guidance and Counselling, Nnamdi Azikiwe University, Akwa, Anambra State, Nigeria \\ ${ }^{2}$ PhD Research Scholar, Department of Guidance and Counselling, Nnamdi Azikiwe University, Akwa, \\ Anambra State, Nigeria
}

Article DOI: $\underline{\text { https://doi.org/10.36713/epra9438 }}$ DOI No: 10.36713/epra9438

\section{ABSTRACT}

Understanding a student's learning style preference is an important consideration when designing classroom instruction. This study investigated learning styles of secondary school students and their implication for guidance and counselling in Awka Education zone, Anambra State. The study adopted a descriptive survey research design. A multi-stage sampling procedure was adopted and used in selecting a sample size of 1,241 students from a population of 6,279 students in public secondary schools. A validated questionnaire titled, Learning Style Questionnaire was used to collect data for the study. The questionnaire has reliability coefficient alphas of $0.68,0.64$ and 0.77 on each of the learning style cluster. The questionnaire was administered through direct delivery approach. Data was collected and analysed using percentages. The findings revealed that majority of the students have good visual, auditory and kinaesthetic learning styles. Based on the findings, the following recommendations among others were made that school guidance counsellors should take into account the students 'diverse learning styles in order to design counselling strategies that take care of those diversities and remain sensitive of such during their learning process.

KEYWORDS: Learning Styles, secondary school, implications, guidance and Counselling, students

\section{INTRODUCTION}

The way people learn and process new information they are taught is one of the many factors that make each individual person unique. In order to enhance the learning experience of learners, it is purported by some that having an understanding of their learning styles can achieve this. Once these styles have been identified, curriculum can be developed which create an effective learning environment. Several inventories have been developed that assess both learning style and teaching style. By utilizing varied inventories, several aspects of learning can be evaluated.

Many researchers agree that learning styles play an important role in education. For example, Felder (1996) points out those learners with a strong preference for a specific learning style may have difficulties in learning if the teaching style does not match with their learning style. Learning style is both a characteristic which indicates how a student learns and likes to learn, as well as instructional strategy informing the cognition, context and content of learning. Thus, learning styles according to Reed and Oughton, (2007) refer to how individuals prefer to organize and represent information. Learning style is thus connected to both a set of behavioural strategies in the way of managing and organizing the information, as well as the way of implementing those strategies.

Moreover, according to Dunn (1994), the inability of schools and teachers to take account of individual learning preferences tends to produce endemic low achievement and poor motivation among students. In many cases, neither students nor teachers are aware that difficulty in learning may not rest solely in the material itself. This assertion was expounded by Domino (2010) whose study revealed that college students taught in their preferred learning styles scored higher on tests, fact knowledge, attitude and efficiency than those taught in instructional styles different from their preferred style. Mismatch of teaching styles and learning styles therefore could actually have negative impact to students learning process.

More so, research according to Felder and Silverman (2008) demonstrated that students whose learning style is not in accordance with their learning preferences tend to be bored and inattentive in class, do poorly on tests, easily get discouraged about the subject matter and may conclude that they are not good in the subject and give up. Learning style thus is used to describe individual differences in the way people learn, as each person has a unique way to absorb and process experiences and information. The learning style considered in this study include; visual, audio-visual and kinaesthetic learning capability.

Visual learners need to see information. They have strong visualization skills and can remember objects, shapes, and pictures. Hence they learn by reading, and by watching films, videos, and demonstrations. Visual earners like to learn through written language, such as reading and writing tasks. They remember what has been written down, even if they do not read it more than once. They like to write down directions and pay better attention to lectures if they watch them. Learners who are visual-spatial usually have difficulty with the 
written language and do better with charts, demonstrations, videos, and other visual materials. They easily visualize faces and places by using their imagination and seldom get lost in new surroundings.

Similarly, auditory learners need to hear information. They have a good sense of hearing and can hear differences in tones and rhythm. Hence they benefit more from reading out loud and can easily remember what they hear in the classroom. Auditory learners tend to benefit most from traditional teaching techniques. Many teachers use a lecture-style forum, presenting information by talking to their students. Regulating voice tone, inflection, and body language will help all students maintain interest and attention. Auditory learners succeed when directions are read aloud, speeches are required, or information is presented and requested verbally.

Kinesthetic learners on the other hand need to be physically active in doing things. They are hands-on learners, have good coordination and learn by doing. Kinesthetic learners are most successful when totally engaged with the learning activity. They acquire information fastest when participating in a science lab, drama presentation, skit, field trip, dance, or other active activity. Because of the high numbers of kinesthetic learners, education is shifting toward a more hands-on approach and manipulative approaches incorporated into almost every school subject, from physical education to language arts.

As classrooms continue to integrate more of these techniques, and once students understand their learning styles, they can better adapt to their learning environment. Therefore, in view of the above explanations, learning style as it relates to this study refers to the way in which secondary school students concentrate on, process, internalize and retain new and difficult academic information which is measured in terms of their visual, audio-visual and kinaesthetic learning competence.

Previous studies have reported that students' learning performance could be improved if proper learning style dimensions could be taken into consideration when developing any learning or instructional process (Graf, Liu, \& Kinshuk, 2010). An example of such studies include Akinbobola (2015) and Ibeh (2015) whose study ascertained the effects of learning styles on the performances of Senior Secondary School Biology and Physics students in Nigeria. The findings thus suggested that students need to understand which learning style translates to their overall outcome in school. Unfortunately, the findings have not translated to significant improvement in academic achievement of the students in Anambra State, possibly because they were not the focus in the studies.

This therefore is a gap that needs to be filled. Counsellors and teachers need to get down working, but needing a working guide. They may have understanding of the advantages of students adhering to a workable learning style, and need to understand clearer how it relates to their achievement outcomes in school. This therefore, has necessitated this study, to investigate the relationship between learning style and the academic achievement of the secondary schools students in Anambra State.

\section{Statement of the Problem}

One of the major problems among students is inability to mobilize cognitive strategies that would help to learn effectively which have often translated to poor academic performance. This has manifested itself in large number of failures recorded in local and national examinations results such as senior school certificate examinations like West African Examination Council (WAEC) and National Examination Council (NECO). This has led to various researches into the learning styles of various professions which occurred throughout the years.

Many studies thus have been conducted to determine if particular groups of students fall into one specific type of learning style (example, Baker, Pesut, McDaniel, \& Fisher, 2007; Breckler, Joun, \& Ngo,2009; French,Cosgriff, \& Brown,2007). Many of the researchers are of the view that if a specific learning style is prevalent in a particular profession, then perhaps training programs for the vocation could create a teaching environment which could enhance that learning style. However, there is still an existing gap in literature on the learning styles of secondary school students in Anambra state which could have many implications for guiding and counselling students in secondary schools in Awka Education Zone, Anambra state, Nigeria. This therefore has motivated this study.

\section{PURPOSE OF THE STUDY}

The main purpose of the study is to investigate learning styles of secondary school students and its implication for guidance and counselling in Awka Education zone, Anambra state, Nigeria. Specifically, the study sought to examine:

1. The visual learning styles of secondary school students in Awka Education Zone.

2. The auditory learning styles of secondary school students in Awka Education Zone?

3. The kinaesthetic learning styles of secondary school students in Awka Education Zone.

\section{Significance of the Study}

The findings of this study will be of benefit to the students, guidance counsellors, teachers, policy makers, parents and future researchers. The findings of the study will be of immense benefit to the guidance counsellors as it will likely broaden the frontiers of knowledge in the area of guidance and counselling. The findings of the study will also assist counsellors greatly in enhancing students' utilisation of their learning preferences to enhance academic performance, especially in core subject areas like English and Mathematics. They could equally organise seminars and workshops to enlighten students on developing good learning styles so that the secondary school students will reach their optimum achievement in their academics.

\section{Research Questions}

The following research questions guided the study:

1. What are the visual learning styles scores of secondary school students in Awka Education Zone?

2. What are the auditory learning styles scores of secondary school students in Awka Education Zone?

3. What are the kinaesthetic learning styles scores of secondary school students in Awka Education Zone? 


\section{Theoretical Framework}

\section{Dunn and Dunn Learning Style Theory}

The Dunn and Dunn learning style addresses how students take in, process, integrate and retain information. They describe learning in the context of stimuli of which there are five: environmental, emotional, sociological, physiological, and psychological processing. Within each of the five stimuli, Dunn and Dunn have described four elements thereby making 20 total elements which comprise learning. Environmental addresses the features within the setting that learning is taking place, such as lighting, sounds, temperature and seating. Emotional aspects are innate factors such as one's motivation, persistence, structural needs, and sense of responsibility. The sociological stimuli relates to whether one prefers to learn in a group setting or by oneself, with colleagues/peers, with a student-teacher dynamic, or in a varied manner. Physiological factors are those which are addressed in the VARK model, visual, auditory, kinesthetic, as well as one's energy level and physical needs. Lastly, the psychological factors take into account whether one is impulsive or reflective and how one processes information.

\section{METHODOLOGY \\ Research Design}

The study adopted a descriptive survey research design. A survey research design is one which a group of items is studied by collecting and analysing data from only a few people or items considered to be representative of the entire population (Akuezuilo \& Agu 2015). In this case, the design enabled the researcher to collect and analyse the characteristics of a whole population or situation by studying a representative sample.

\section{Area of the Study}

This study was carried out in Awka education zone, Anambra State. Anambra State is a state in Southern Nigeria. The state comprised of six education zones of which Awka Education Zone is one of them. The zone also has the highest number of public secondary schools in the State.

\section{Participants}

The sample for the study consist of 1, 260 students. This comprise of all the SS2 students that were chosen from government owned secondary schools in Awka Education Zone, through a multi-stage sampling method.

\section{Instrument for Data Collection}

The instrument for data collection consists of questionnaire titled "Learning Style Questionnaire". This is an adapted version of the modality (learning channel preference) questionnaire initially developed by O'Brien (1985) and tailored to suit the purpose of this study. The instrument is a 24 item questionnaire describing characteristics of Visual, Auditory, and Kinesthetic learning styles. There are 8 items measuring each style. The questionnaire has response options of Always, Sometimes, Rarely, and Never, with weighted values of 4, 3, 2 and 1 respectively. The modality type with the highest score indicates the students' preferred learning channel; the higher the score, the stronger the preference. The internal consistency reliability of the instrument was determined; yielding a coefficient alpha of 0.94 for the Learning Style Questionnaire. This was determined using Cronbach alpha statistical method.

\section{Data Collection and Analysis}

The researcher administered 1, 260 copies of the instruments through direct delivery method. The administered questionnaire after collection were scored in line with the instrument scoring guide and analysed using statistical package for social science (SPSS), and the statistical tools used include summated scores and percentages for research questions.

\section{RESULTS}

In this section, the data collected from the field for this study were analysed and the summaries presented in tables to highlight the findings as follows:

\section{Research Question 1}

What are the visual learning style scores of secondary school students in Anambra state?

\begin{tabular}{llcc} 
Range of scores & N & \% & Remarks \\
\hline $8-19.92$ & 49 & 3.9 & Poor visual learning style \\
$20-32$ & 1192 & 96.1 & Good visual learning style \\
\hline
\end{tabular}

Table 1 shows that $1192(96.1 \%)$ of the students with the scores ranging from 20 to 32 have good visual learning style, while $49(3.9 \%)$ of the students who scored between 8 Research Question 2

What are the auditory learning style scores of and 19.92 have visual learning style. secondary school students in Anambra state?

Table 2: Range of scores on students' auditory learning style

\begin{tabular}{lccc} 
Range of scores & $\mathbf{N}$ & $\mathbf{\%}$ & Remarks \\
\hline $8-19.92$ & 60 & 4.8 & Poor auditory learning style \\
$20-32$ & 1181 & 95.2 & Good auditory learning style
\end{tabular}

Table 2 reveals that $1181(95.2 \%)$ of the students with the scores ranging from 20 to 32 have good auditory learning style, while $60(4.8 \%)$ of the students who scored between 8 and 19.92 have auditory learning style.

\section{Research Question 3}

What are the kinesthetic learning style scores of secondary school students in Anambra state? 
Table 3: Range of scores on students' kinaesthetic learning style

\section{Range of scores}

$8-19.92$

$20-32$

\begin{tabular}{cc}
$\mathbf{N}$ & $\%$ \\
\hline 174 & 14.0 \\
1167 & 86.0
\end{tabular}
86.0
Remarks

Poor kinaesthetic learning style

Good kinaesthetic learning style
Table 3 indicates that $1167(86.0 \%)$ of the students with the scores ranging from 20 to 32 have good kinaesthetic learning style, while $174(14.0 \%)$ of the students who scored between 8 and 19.92 have kinaesthetic learning style.

\section{DISCUSSIONS}

The findings of the study are hereby discussed.

Findings from the study revealed that majority of the students have good visual, auditory and kinaesthetic learning styles. This means that majority of the students' natural or habitual pattern of acquiring and processing information in learning situations fall within the three learning styles. Hence, many of these students could get learning information from visual images (schematics, graphs, diagrams, pictures and demonstrations) when their sight is engaged. A good number of them could also remember and understand new concepts better when they are explained out loud through their sense of hearing, even if they're doing the speaking themselves. More so, the findings also revealed that majority of these students could absorb information through touch, movement and motion. In that sense, they learn when they touch it, feel it and move it around. This finding of the study is in agreement with Akinbobola (2015) whose study noted that students can possess more than one learning style and that the three learning styles could be used for the enhancement of students learning.

Understanding of the students learning styles could provide useful information, as well as providing a clue to the variables that are likely to influence learning in schools. Learning styles thus describe the factors, often extrinsic, that increase one's knowledge gains and leads to enhanced integration of information. Learning styles also define how an individual learns most effectively. In addition, learning styles consider the uniqueness of each person in the context of learning and emphasizes individual differences while at the same time allowing for integration of certain teaching practices in the classroom by incorporating different teaching strategies or by providing different experiences for the learner.

\section{CONCLUSIONS}

Based on the findings of this study, it was concluded that that students use different preferred learning styles to learn, need to be taken into account to improve students' learning. It could be understood from the results that there is a similar preference for more than one learning styles among the students. As a result, it could be inferred that most students possessed multiple learning styles or a combination of different learning styles. As such, they can be able to learn effectively.

\section{IMPLICATION OF THE STUDY TO GUIDANCE AND COUNSELLING}

The results from this study could be relevant in organising counselling programs for students in secondary schools. While there are many aspects that may affect student learning, one specific area is having a better understanding of the best way as student learns in school and the internal and external factors that either augment or hinder one's learning. These factors can include the physical environs, perceived support from the school and the relevance of presented information, as well as the personal relationships among classmates.

Also knowledge of the students learning styles could help the guidance counsellor in the assessment of the students' developmental needs as one of the main responsibilities of teachers and specialists working with them.

It could also help provide psychological and pedagogical support aims to help pupils fulfil their developmental potential and create conditions for their active and full participation in the life of their school and in their social environment. It could also help the guidance counsellor in identifying reasons behind academic failures or difficulties in pupils' functioning, including barriers and constraints which make it difficult for them to function and participate in the life of their school; taking measures which help pupils develop their competences and potential in order to enhance the effectiveness of their learning process and improve their functioning.

\section{RECOMMENDATIONS}

Based on the findings of the study, the researcher made the following recommendations:

1. School guidance counsellors should take into account their students 'diverse learning styles, design counselling strategies that take care of those diversities and remain sensitive of such during the instruction process.

2. Students who fall within the low academic achievers should be identified by the school guidance counsellors and direct individual and group counselling approaches should be utilized to help them improve their learning styles.

3. The school guidance counsellors should provide psychological and pedagogical support aims to help pupils fulfil their developmental potential and create conditions for their active and full participation in the life of their school and in their social environment.

\section{REFERENCES}

1. Akinbobola, A. O. (2015). Effects of learning styles and instructional strategies on students' achievement in Nigerian senior secondary school physics.Advances in Physics Theories and Applications, 41. Retrieved from www.iiste.org

2. Baker, C., Pesut, D., McDaniel, A., \& Fisher, M. (2007). Evaluating the impact of problem-based learning on learning styles of master's students in nursing administration. Journal of Professional Nursing, 23(4), 214-219.

3. Breckler, J., Joun, D., \& Ngo, H. (2009). Learning styles of physiology students interested in the health professions. Advances in Physiology Education, 33, 30-36. 
4. Domino, K.S. (2010). Academic achievement and study behaviour: A process Approach, $\left(7^{\text {th }}\right.$ Edition). New Yourk, NY: McGraw-Hill.

5. Dunn, R. (1994). The Dunn and Dunn learning styles model:Theory, research, and application. In Shaughnessy, M.F., (Ed.). Education in the 21st century. NM: Eastern New Mexico University, pp. 131-141.

6. Felder, J.D.\&Silverman, K.A (2008). The thrill of victory, the complexity of Defeat: Self-esteem and peoples emotional reactions to success and failure. Journal of Personality and Social Psychological, 68(4). 712-722

7. Felder, R.M. (1996). Matters of style. ASEE Prism, 6(4), 1823.

8. Felder, R.M. and Spurlin, J., (2005). Applications, reliability and validity of the index of learning styles. International Journal on Engineering Education, 21(1), 103-112.

9. French, G., Cosgriff, T., \& Brown, T. (2007). Learning style preferences of Australian occupational therapy students. Australian Occupational Therapy Journal, 54, S58-S65

10. Graf, S., Liu, T. C., \& Kinshuk.(2010). Analysis of learners navigational behaviour and their learning styles in an online course. Journal of Computer Assisted Learning, 26(2), 116-131.

11. Ibeh, H.N. (2015). Effects of learning styles on the performances of senior secondary school biology students.An International Multidisciplinary Journal, Ethiopia, 9(1), 214- 227.

DOI:http://dx.doi.org/10.4314/afrrev.v9i1.17. Retrieved from http://afrrevjo.net/journals/multidiscipline/

12. Kinsella, K. (1996). Designing group work that supports and enhances diverse classroom work styles. TESOL Journal, 6(1), 24-31.

13. Reed, K.L., \& Oughton, D.M (2007). Effects between motivational goals, learning style and academic achievement: What is the causal ordering? Paper presented at the Australian Association of Educational Research (AARE): 